University of Nebraska - Lincoln

DigitalCommons@University of Nebraska - Lincoln

\title{
Geochemical investigations of metals release from submerged coal fly ash using extended elutriate tests
}

\author{
A. J. Bednar \\ US Army Engineer Research and Development Center, anthony.j.bednar@usace.army.mil
}

M. A. Chappell

US Army Engineer Research and Development Center

J. M. Seiter

US Army Engineer Research and Development Center

J. K. Stanley

US Army Engineer Research and Development Center

D. E. Averett

US Army Engineer Research and Development Center

See next page for additional authors

Follow this and additional works at: https://digitalcommons.unl.edu/usarmyresearch

Part of the Operations Research, Systems Engineering and Industrial Engineering Commons

Bednar, A. J.; Chappell, M. A.; Seiter, J. M.; Stanley, J. K.; Averett, D. E.; Jones, W. T.; Pettway, B. A.; Kennedy, A. J.; Hendrix, S. H.; and Steevens, J. A., "Geochemical investigations of metals release from submerged coal fly ash using extended elutriate tests" (2010). US Army Research. 107.

https://digitalcommons.unl.edu/usarmyresearch/107

This Article is brought to you for free and open access by the U.S. Department of Defense at DigitalCommons@University of Nebraska - Lincoln. It has been accepted for inclusion in US Army Research by an authorized administrator of DigitalCommons@University of Nebraska - Lincoln. 


\section{Authors}

A. J. Bednar, M. A. Chappell, J. M. Seiter, J. K. Stanley, D. E. Averett, W. T. Jones, B. A. Pettway, A. J. Kennedy, S. H. Hendrix, and J. A. Steevens 


\title{
Geochemical investigations of metals release from submerged coal fly ash using extended elutriate tests
}

\author{
A.J. Bednar*, M.A. Chappell, J.M. Seiter, J.K. Stanley, D.E. Averett, W.T. Jones, B.A. Pettway, \\ A.J. Kennedy, S.H. Hendrix, J.A. Steevens \\ US Army Engineer Research and Development Center, Environmental Laboratory, 3909 Halls Ferry Rd., Vicksburg, MS 39180, United States
}

\section{A R T I C L E I N F O}

\section{Article history:}

Received 28 July 2010

Received in revised form 7 September 2010

Accepted 8 September 2010

Available online 12 October 2010

\section{Keywords:}

Fly ash

Dredging

Speciation

Metal mobility

\begin{abstract}
A B S T R A C T
A storage pond dike failure occurred at the Tennessee Valley Authority Kingston Fossil Plant that resulted in the release of over 3.8 million cubic meters ( 5 million cubic yards) of fly ash. Approximately half of this material deposited in the main channel of the Emory River, $3.5 \mathrm{~km}$ upstream of the confluence of the Emory and Clinch Rivers, Tennessee, USA. Remediation efforts to date have focused on targeted removal of material from the channel through hydraulic dredging, as well as mechanical excavation in some areas. The agitation of the submerged fly ash during hydraulic dredging introduces river water into the fly ash material, which could alter the redox state of metals present in the fly ash and thereby change their sorption and mobility properties. A series of extended elutriate tests were used to determine the concentration and speciation of metals released from fly ash. Results indicated that arsenic and selenium species released from the fly ash materials during elutriate preparation were redox stable over the course of $10 \mathrm{~d}$, with dissolved arsenic being present as arsenate, and dissolved selenium being present as selenite. Concentrations of certain metals, such as arsenic, selenium, vanadium, and barium, increased in the elutriate waters over the $10 \mathrm{~d}$ study, whereas manganese concentrations decreased, likely due to oxidation and precipitation reactions.
\end{abstract}

Published by Elsevier Ltd.

\section{Introduction}

On December 22, 2008 a dike failure released over 3.8 million cubic meters of coal fly ash from the Tennessee Valley Authority Kingston Fossil Plant located near the confluence of the Emory and Clinch Rivers in Tennessee (Ruhl et al., 2009; TVA, 2009; USEPA, 2009). Approximately 2.3 million cubic meters of this material deposited in the Emory River, filling the navigation channel with up to $9 \mathrm{~m}$ of fly ash. The spill covered about $120 \mathrm{Ha}$ (300 acres) in fly ash material (TVA, 2009; USEPA, 2009). The volume of the release was at least 8-fold greater than any previous coal ash release in US history, the largest previous spills being the Clinch River, VA, 1967 spill of over 480000 cubic meters of alkaline fly ash leachate (Roy et al., 1981), and the Martins Creek, PA, 2005 spill of nearly 377000 cubic meters of a fly ash and water mixture (PA DEP, 2005).

Recovery of the material from the river thus far has primarily been performed by hydraulic cutterhead dredges pumping the ash from the river bottom through a pipeline into an ash recovery ditch where the heavier ash particles that settle quickly are removed by a mechanical excavator for disposal. The remaining

\footnotetext{
* Corresponding author. Tel.: +1 6016343652.

E-mail address: Anthony.J.Bednar@usace.army.mil (A.J. Bednar).
}

suspended ash and water flow into the plant sluice channel and mix with plant process water before flowing into an ash settling pond that overflows into a stilling pond for final effluent polishing. Additional fly ash recovery from the area has been by mechanical excavation. Remediation and recovery efforts have been underway since March 2009, with over 1.5 million cubic meters of fly ash material removed as of December 2009.

Although the major constituents of fly ash are similar to those of natural soils and rocks, fly ash tends to be enriched in many trace metals (Guthrie et al., 1982; Eary et al., 1990; Mattigold et al., 1990; Gieré et al., 2003; Chaudhary and Banerjee, 2007). Furthermore, the $\mathrm{pH}$ dependent leaching of metal ions (e.g., arsenic, cadmium, chromium, zinc, lead, mercury, selenium) (Baba et al., 2008) raises concern regarding potential for toxic effects if contacted by aquatic receptors (Roy et al., 1981; Carlson and Adriano, 1993; Rowe et al., 2002; Kuzmick et al., 2007). The physical effect of siltation, followed by reductions in $\mathrm{pH}$ (and associated metal increased leaching) have been reported to retard the recovery of indigenous benthic macroinvertebrates in basins silted by fly ash due to chronic impairment (Cherry et al., 1979, 1984), and although the Kingston event was a single large release, residual fly ash will remain in the river system for an extended period of time.

Selenium released from coal fly ash, in particular, has been the subject of previous studies on bioaccumulation in fish (Besser 
et al., 1996). Along with arsenic, chromium, barium, and vanadium, selenium is of concern in the Kingston fly ash material. There is a potential for negative impacts to the Emory River ecosystem resulting from the deposited fly ash and subsequent release of metals during recovery activities, since fly ash agitation and mixing with river water may cause enhanced metal mobility and bioavailability. In particular, selenium, arsenic, and mercury have been cited as potential contaminants of concern for the Emory River (Chatterjee, 2009; Ruhl et al., 2009; USEPA, 2009).

This research investigates the potential release of metals from the fly ash material using elutriate tests that simulate extreme redox boundary conditions resulting from disturbance of the material during dredging (Palermo et al., 2008) and disposal (USACE, 2003). The elutriate experiments were extended to $10 \mathrm{~d}$ in order to create the redox conditions for possible reactions involving the metals to occur. Two types of elutriate agitation were used, namely, bubbling of the water-ash slurry with either air or nitrogen, to create redox conditions that could affect concentration and speciation of released metals.

\section{Experimental}

\subsection{Reagents}

All chemicals used were of reagent grade or higher purity and used without further purification; the deionized water used had a resistivity of $18.3 \mathrm{M} \Omega \mathrm{cm}$. Nitric acid (OmniTrace grade) and hydrogen peroxide were purchased from Fisher Scientific (Waltham, MA). NIST-traceable mixed analyte calibration standards were purchased from SPEX CertiPrep (Metuchen, NJ) and CPI International (Santa Rosa, CA). Sodium salts of arsenite, arsenate, selenite, and selenate for speciation analysis were purchased from Sigma Aldrich (Atlanta, GA). Speciation calibration standards were made in $0.25 \mathrm{mM}$ EDTA and stored in the dark to preserve the species distribution (Bednar et al., 2002).

\subsection{Field sample collection}

All field samples were collected on 12 June 2009 and immediately packed on ice and transported overnight to the US Army Engineer Research and Development Center (ERDC) in Vicksburg, MS; elutriate preparations were initiated on 13 June 2009. Fly ash from the Emory River was collected by boat using a polypropylene shovel. Five discrete subsamples were collected approximately $3.5 \mathrm{~km}$ upstream of the confluence of the Emory and Clinch Rivers near $\mathrm{N}$ $35^{\circ} 54.877^{\prime}, \mathrm{W} 084^{\circ} 30.163^{\prime}$. The samples were taken in areas where the fly ash was submerged in the river at depths less than $1 \mathrm{~m}$, composited after collection by mixing with the shovel until visually homogenous, and passed through a $1.25 \mathrm{~cm}$ sieve to remove any large debris. The homogenized samples were placed into two $19 \mathrm{~L}$ plastic buckets and packed on ice for transportation.

Samples of fly ash were also collected from the top of the fly ash storage pile in an area that did not collapse during the embankment failure. This material was used as a control to determine the metals originally present in the fly ash material before submersion. Three composite samples were taken using a sediment corer near $\mathrm{N} 35^{\circ} 54.550^{\prime}$, $\mathrm{W} 084^{\circ} 30.770^{\prime}$. At each sampling site, the upper $5 \mathrm{~cm}$ was scraped away prior to sampling to remove the stabilizer material added to the storage pile, with sediment cores taken to a depth of $0.5 \mathrm{~m}$. These samples were composited, homogenized, and placed into three $1 \mathrm{~L}$ bottles on ice for transportation.

Reference Emory River water was collected from the Emory River near river mile 12 upstream of the river fly ash sampling point ( $\mathrm{N} 35^{\circ} 55.995^{\prime}$, W $084^{\circ} 33.554^{\prime}$ ). This water was collected using an electric pump from a depth of $0.75 \mathrm{~m}$ at a $1.5 \mathrm{~m}$ deep site located
$8 \mathrm{~m}$ out from the shoreline. The pump and associated hoses were flushed with site water for 15 min prior to sampling. Water was collected in 208 L HDPE drums, and bags of ice were packed around the exterior of the drums for transportation.

Fly ash material was collected from the ash recovery ditch $(\mathrm{N}$ $35^{\circ} 54.192^{\prime}, \mathrm{W} 084^{\circ} 31.020^{\prime}$ ) used to allow settling of hydraulically dredged fly ash from the Emory River. Fly ash was sampled from the bottom of the ash ditch, to a depth of approximately $1 \mathrm{~m}$, using an excavator. Water was also collected from the ash recovery ditch into $16 \mathrm{~L}$ cubitainers using an electric pump after flushing for $5 \mathrm{~min}$. The fly ash and water samples were packed on ice for transportation.

The Emory River water and fly ash materials were used to create Emory River elutriates (labeled EMR), whereas the ash recovery ditch water and fly ash materials were used to create ash recovery ditch elutriates (labeled ARD), as described in the following section.

Finally, a water sample was taken from the effluent of the stilling pond just prior to discharge into the Emory River (N 35 $54.279^{\prime}$, $\left.\mathrm{W} 084^{\circ} 30.363^{\prime}\right)$. The stilling pond receives the water from the ash recovery ditch via the sluice channel and ash pond. Plant process water and suspended ash are released to the Sluice channel and mix with the dredging stream. The stilling pond represents the final settling stage for the dredged water before release back to the Emory River. Two replicate $1 \mathrm{~L}$ grab samples were collected just under the water's surface, and were used to determine the concentration of metals after dredging and ash settling in the field recovery and treatment system. The samples were packed on ice during transportation to the laboratory.

\subsection{Extended aeration elutriate tests}

A modification of the Dredging Elutriate Test (DRET) was used to simulate sediment disturbance during hydraulic dredging operations and test an extreme case of disturbance and oxidation to determine the potential for metals release and speciation change. The standard DRET involves suspending 1-10 g of solid material in site water with agitation for $1 \mathrm{~h}$, followed by $1 \mathrm{~h}$ of settling, after which the supernatant is collected for analysis (Palermo et al., 2008). This procedure was modified to include continuous agitation for $240 \mathrm{~h}$, with whole water aliquots taken for analysis at 1 (standard procedure time point), 24, 48, 96, and $240 \mathrm{~h}$. At each time point, whole water samples were collected and allowed to settle for $1 \mathrm{~h}$ according to the standard DRET procedure. After settling, the supernatant water was decanted and analyzed for metals concentrations and select metals species. Additionally, two redox conditions were tested, created by bubbling the elutriate systems with humidified air or nitrogen during the preparation period (240 h). Both the Emory River fly ash and river water and the ash recovery ditch fly ash and water elutriates were prepared in triplicate from a single composite ash sample. The fly ash loading of $5.3 \mathrm{~g} \mathrm{~L}^{-1}$ for the Emory River elutriates and $8 \mathrm{~g} \mathrm{~L}^{-1}$ for the ash recovery ditch elutriates are within method guidance (Digiano et al., 1995; Palermo et al., 2008) and are within the range of solids loads in the ash recovery system.

\subsection{Sample preparation}

Aqueous samples were analyzed for total and dissolved metals concentrations. Samples were filtered through a $0.45 \mu \mathrm{m}$ pore size syringe filter and acidified with nitric acid for determination of dissolved concentrations, whereas total metals concentrations were determined on whole water samples after digestion following Method 3005 (USEPA, 2007). Aqueous samples for elemental speciation were also filtered through a $0.45 \mu \mathrm{m}$ syringe filter prior to preservation and dilution with $0.25 \mathrm{mM}$ EDTA solution (Bednar et al., 2002, 2004; Bednar et al., 2009). Solid samples were air dried, 
ground, and sieved to pass a \#40 ASTM sieve (Felt et al., 2008) and then digested following Method 3050B (USEPA, 2007).

\subsection{Instrumentation}

Metal concentrations for all solid and aqueous samples were analyzed using ICP-AES or ICP-MS as appropriate for the concentration ranges observed for major and trace elements following methods 6010C and 6020A (US EPA, 2007) using a Perkin Elmer (Wellesley, MA) Optima 5300DV ICP-AES or Elan DRC-II ICP-MS, respectively. Selenium and arsenic speciation was determined by High Performance Liquid Chromatography-ICP-MS (HPLC-ICP-MS) using an Agilent (Palo Alto, CA) 1100 HPLC interfaced to the Perkin Elmer Elan DRC-II ICP-MS with a MiraMist pneumatic nebulizer as previously described (Bednar et al., 2004, 2009). Mercury was determined using a PS Analytical (Deerfield, FL) Millennium Merlin cold vapor atomic fluorescence spectrometer following Method 7471 (US EPA, 2007).

All analytical standards for metals determination by ICP-AES and ICP-MS were NIST-traceable, and purchased from SPEX CertiPrep (Metuchen, NJ) and CPI International (Santa Rosa, CA). Calibration and check standards were diluted in $1 \%$ trace-metal grade nitric acid to appropriate calibration ranges $\left(1-100 \mu \mathrm{g} \mathrm{L}^{-1}\right.$ for ICP-MS and $0.1-10 \mathrm{mg} \mathrm{L}^{-1}$ for ICP-AES) Scandium, Yittrium, Rhodium, Terbium, and Holomium were added on-line with a mixing-T prior to introduction into the plasma nebulizer for use as internal standards. Variations in internal standard intensity were less than $15 \%$. Second source verification and continuing calibration verification standards were analyzed periodically in each analytical batch with recovery for all analytes within $10 \%$ of the certified value; additionally, a commercially available reference solution from Environmental Resource Associates (Golden, CO; Lot number P136-500) was also analyzed in each analytical batch with analyte recoveries within $20 \%$ of the certified value. Duplicate and matrix spike samples were included in each analytical batch, with duplicate precision demonstrated by relative percent differences of $<20 \%$ and matrix spike recoveries within $20 \%$ of the nominal spike concentration for all analytes. Total organic carbon was measured using a Shimadzu TOC-V following Method 9060 (US EPA, 2007).

Redox potential in elutriate samples was measured using a platinum electrode with a silver-silver chloride reference and a field portable meter. The accuracy of the redox probe was verified using Light's solution, which yields a value of $476 \mathrm{mV}$; the Light's Solution check standard readings were within $\pm 10 \mathrm{mV}$ of this value, which is deemed acceptable (Light, 1972) and were checked daily. A combination electrode was used to measure $\mathrm{pH}$ and was calibrated daily using standard buffers at $\mathrm{pH}=4.0$ and 7.0.

\section{Results and discussion}

\subsection{Field water and fly ash analyses}

Concentrations of metals in the three fly ash samples collected from the site were quantified, as were total organic and inorganic carbon, as listed in Table 1 . The values reported for these samples are similar to those reported by others (Ruhl et al., 2009). There is some heterogeneity in the three samples, likely due to different coal sources and weathering over the 60 year storage history, as well as mixing that occurred during the river deposition event.

However, differences in concentrations between the Emory River and ash recovery ditch samples are suggestive, but are not absolute indicators, of potential metals leaching from the fly ash material during dredging operations. Many elements decrease in concentration from the Emory River fly ash to the recovery ditch fly ash; however, arsenic, iron, and manganese increase (cadmium,
Table 1

Concentrations of metals (dry weight) in the solid phase fly ash samples collected from the TVA Kingston site.

\begin{tabular}{llll}
\hline & \multicolumn{2}{l}{ Concentration $(\mathrm{mg} / \mathrm{kg})$} & \\
\cline { 2 - 4 } Analyte & Emory River & Recovery Ditch & Storage Pile \\
\hline TOC $^{\mathrm{a}}$ & 44930 & 16780 & 51840 \\
TIC $^{\mathrm{b}}$ & 170 & 370 & 120 \\
Aluminum & 30600 & 29900 & 18600 \\
Antimony & 0.233 & 0.212 & 0.145 \\
Arsenic & 65.8 & 76.2 & 46.9 \\
Barium & 655 & 515 & 510 \\
Beryllium & 7.15 & 6.03 & 4.88 \\
Cadmium & 0.576 & 0.631 & 0.272 \\
Calcium & 9090 & 6510 & 6780 \\
Chromium & 48.7 & 49.2 & 33.5 \\
Cobalt & 25.6 & 23.1 & 16.9 \\
Copper & 84.1 & 76.4 & 50 \\
Iron & 17700 & 22200 & 17500 \\
Lead & 36.4 & 33.1 & 20.2 \\
Magnesium & 2780 & 2380 & 1940 \\
Manganese & 153 & 187 & 88.7 \\
Mercury & 0.0732 & 0.0294 & 0.0279 \\
Molybdenum & 4.04 & 4.23 & 3.2 \\
Potassium & 4690 & 4890 & 2760 \\
Nickel & 52.6 & 49.9 & 34 \\
Selenium & 6.97 & 6.08 & 5.44 \\
Sodium & 709 & 608 & 482 \\
Silver & 0.426 & 0.335 & 0.22 \\
Thallium & 2.19 & 2.04 & 1.35 \\
Vanadium & 133 & 124 & 86.2 \\
Zinc & 77.4 & 72.1 & \\
\hline Total & & & \\
\hline & & & \\
\hline
\end{tabular}

a Total Organic Carbon.

b Total Inorganic Carbon.

chromium, and molybdenum increase slightly, but are likely within the typical replicate error of the analytical procedures; Felt et al., 2008). Particle fractionation could partially explain the relative increase in iron and manganese, which could also affect sorbed or co-precipitated phases in the ash recovery ditch material (e.g., arsenic), as this sample was collected near the end of the recovery ditch where time for partitioning, sorption, and settling was the greatest.

Site waters collected from the Emory River upstream of the fly ash release area, the ash recovery ditch, and the stilling pond effluent prior to discharge back into the Emory River were also analyzed for total and dissolved metals (Table 2).

The Emory River water sample collected approximately $19 \mathrm{~km}$ upstream represents baseline conditions for elemental concentrations in this system. Generally low levels of dissolved metals were observed, with most being below $0.001 \mathrm{mg} \mathrm{L}^{-1}$ (except barium at 0.031 and zinc at $0.0057 \mathrm{mg} \mathrm{L}^{-1}$ ). Total metals are indicative of suspended material in the river, with concentrations of antimony, arsenic, chromium, copper, nickel, selenium, silver, vanadium, and zinc above $0.001 \mathrm{mg} \mathrm{L}^{-1}$. Total concentrations of most elements increase in the ash recovery ditch water due to the disturbance of the fly ash material with river water during dredging activities resulting in higher solid loads. However, dissolved concentrations of antimony, arsenic, barium, molybdenum, selenium, and vanadium (as well as the major elements) also increase in the ash recovery ditch, compared to the Emory River water. This suggests that the residence time of the dredged material slurry $(\sim 1-2 \mathrm{~h})$ is sufficient for some elements to dissolve or desorb from the fly ash material.

Total and dissolved concentrations of antimony, arsenic, molybdenum, and vanadium decrease significantly in the stilling pond effluent, relative to the ash recovery ditch water, likely due to precipitation and sorption reactions occurring as the remaining fly ash settles and due to dilution from the addition of plant process water from the sluice channel. However, barium and chromium increased in the stilling pond effluent, possibly due to dissolution reactions from colloidal material still suspended in the stilling pond, as well 
Table 2

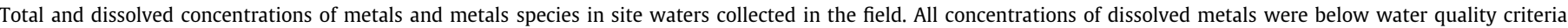
(WQC) established for the protection of aquatic life (US EPA, 2002).

\begin{tabular}{|c|c|c|c|c|c|c|}
\hline \multirow[b]{2}{*}{ Analyte } & \multicolumn{3}{|c|}{ Dissolved Concentration (mg/L) } & \multicolumn{3}{|c|}{ Total Concentration (mg/L) } \\
\hline & Emory River & Recovery Ditch & Stilling Pond & Emory River & Recovery Ditch & Stilling Pond \\
\hline Aluminum & $<0.0500$ & 0.252 & 0.281 & 0.228 & 5.58 & 1.14 \\
\hline Antimony & $<0.0002$ & 0.0081 & 0.0023 & 0.0088 & 0.0411 & 0.0088 \\
\hline Arsenic & 0.0008 & 0.0779 & 0.0208 & 0.0011 & 0.0767 & 0.0192 \\
\hline Barium & 0.0307 & 0.107 & 0.175 & 0.0340 & 0.167 & 0.182 \\
\hline Beryllium & $<0.0002$ & $<0.0002$ & $<0.0002$ & $<0.0004$ & 0.0009 & $<0.0004$ \\
\hline Cadmium & $<0.0002$ & 0.0003 & $<0.0002$ & $<0.0004$ & $<0.0004$ & $<0.0004$ \\
\hline Calcium & 8.55 & 30.7 & 34.7 & 8.93 & 31.0 & 34.4 \\
\hline Chromium & $<0.0002$ & $<0.0002$ & 0.0041 & 0.0010 & 0.0063 & 0.0081 \\
\hline Cobalt & $<0.0002$ & $<0.0002$ & $<0.0002$ & $<0.0004$ & 0.0034 & 0.0012 \\
\hline Copper & 0.0005 & 0.0005 & 0.0012 & 0.0040 & 0.0190 & 0.0090 \\
\hline Iron & 0.0525 & $<0.0500$ & $<0.0500$ & 0.253 & 2.00 & 0.333 \\
\hline Lead & $<0.0002$ & $<0.0002$ & $<0.0002$ & 0.0007 & 0.0065 & 0.0017 \\
\hline Magnesium & 2.1 & 5.15 & 7.34 & 2.17 & 5.47 & 7.38 \\
\hline Manganese & 0.0005 & 0.0296 & $<0.0002$ & 0.0351 & 0.0482 & 0.0235 \\
\hline Mercury & $<0.000005$ & $<0.000005$ & 0.000014 & 0.000148 & 0.000306 & 0.000431 \\
\hline Molybdenum & $<0.0002$ & 0.0733 & 0.0236 & $<0.0004$ & 0.0738 & 0.0236 \\
\hline Nickel & 0.0009 & 0.0005 & 0.0013 & 0.0027 & 0.0115 & 0.0055 \\
\hline Potassium & 1.29 & 1.88 & 2.3 & 1.71 & 4.09 & 2.49 \\
\hline Selenium & $<0.0002$ & 0.0059 & 0.0054 & $<0.0004$ & 0.0046 & 0.0043 \\
\hline Silver & 0.0005 & 0.0004 & 0.001 & 0.0016 & 0.0010 & 0.0023 \\
\hline Sodium & 2.44 & 4.05 & 7.79 & 3.01 & 4.79 & 8.23 \\
\hline Strontium & 0.0424 & 0.544 & 0.353 & 0.0429 & 0.571 & 0.352 \\
\hline Thallium & $<0.0002$ & 0.0005 & 0.0003 & $<0.0004$ & 0.0008 & $<0.0004$ \\
\hline Vanadium & $<0.0002$ & 0.0509 & 0.0317 & 0.0005 & 0.0769 & 0.0390 \\
\hline Zinc & 0.0057 & 0.0058 & 0.0064 & 0.0210 & 0.0334 & 0.0285 \\
\hline $\mathrm{As}(\mathrm{III})$ & $<0.002$ & $<0.002$ & $<0.002$ & & & \\
\hline $\mathrm{As}(\mathrm{V})$ & $<0.002$ & 0.0603 & 0.0148 & & & \\
\hline $\mathrm{Se}(\mathrm{IV})$ & $<0.002$ & 0.0040 & 0.0047 & & & \\
\hline $\mathrm{Se}(\mathrm{VI})$ & $<0.002$ & $<0.002$ & 0.0037 & & & \\
\hline
\end{tabular}

as any barium present in the plant process water entering the sluice channel. Overall, these data suggest that a dynamic equilibrium is being achieved in the fly ash settling system, in which precipitation and sorption of various elements is occurring, while dissolution reactions or colloidal material may continue to increase the concentrations of some elements.

\subsection{Extended elutriate tests}

The extended elutriate tests were designed to test the susceptibility of the fly ash metals to oxidation and solubilization during prolonged disturbance and mixing of fly ash with site water. The air or nitrogen aeration treatments created an extreme set of conditions under which the fly ash was agitated for $10 \mathrm{~d}$, far in excess of actual field conditions.

The total organic carbon concentration, $\mathrm{pH}$, and redox potential (Eh) for the four elutriate systems (EMR and ARD using air or nitrogen purging for agitation) are shown in Fig. 1. The concentrations of organic carbon (Fig. 1) remain relatively constant near $2.5 \mathrm{mg} \mathrm{L}^{-1}$ over the first $96 \mathrm{~h}$ of the elutriate test for the ARD elutriates, with the aerated EMR elutriate slightly higher, near $3 \mathrm{mg} \mathrm{L}^{-1}$, and the nitrogen EMR elutriate slightly higher still, near $5 \mathrm{mg} \mathrm{L}^{-1}$. However, all four systems show a substantial organic carbon increase by $240 \mathrm{~h}$. The increase in total organic carbon between 96 and $240 \mathrm{~h}$ suggests that the efforts to keep the ash materials suspended may have resulted in desorption of organic matter from the suspended fly ash.

Fig. 1 also plots the measured $\mathrm{pH}$ and Eh values for the $10 \mathrm{~d}$ elutriate experiments, with little variability observed between the various elutriate systems. The $\mathrm{pH}$ of all elutriate systems held between 7.25 and 7.75 until $48 \mathrm{~h}$, after which the $\mathrm{pH}$ increased approximately 1.5 units, however, the EMR elutriates generally had lower $\mathrm{pH}$ values throughout the experiment. The Eh drops approximately $50 \mathrm{mV}$ in all systems from 1 to $24 \mathrm{~h}$, followed by a slow increase to near $275 \mathrm{mV}$ by $240 \mathrm{~h}$. Due to the low dissolved concentrations of redox-active elements (e.g. iron, manganese) in
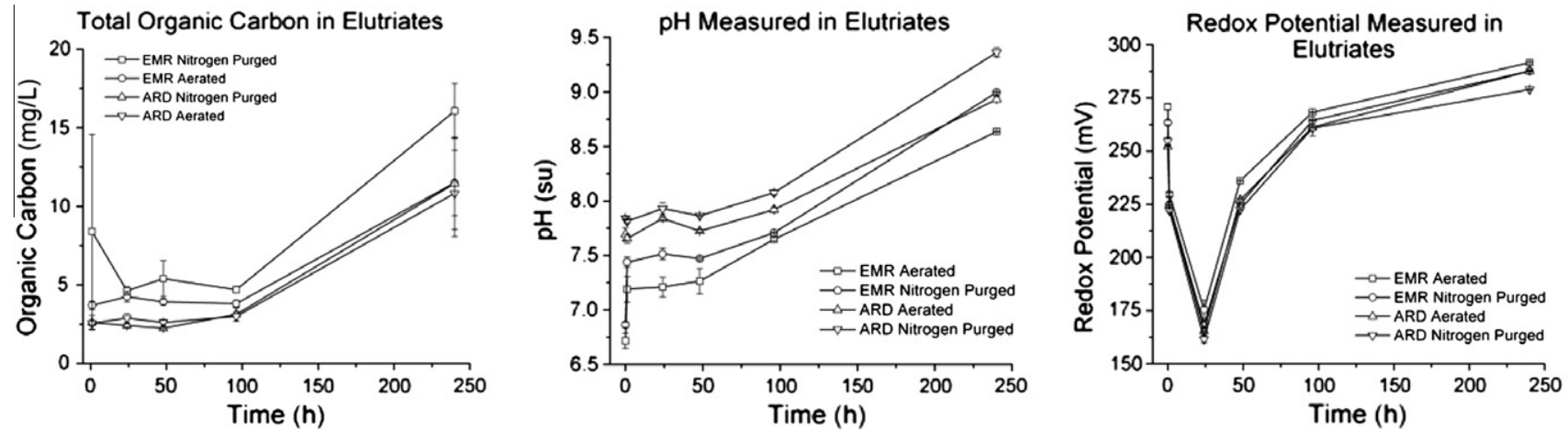

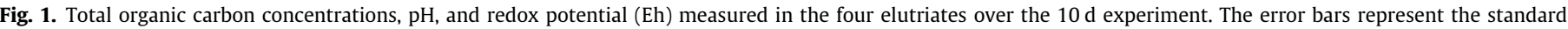
deviation of measurements on triplicate elutriate preparations. 
these systems, we hypothesize that the redox potential may be strongly influenced by organic matter, as the Eh increases follow the increases in organic carbon concentration, with essentially no difference observed between aerated and nitrogen conditions.

The concentrations of major cations in the four elutriate systems are shown in Fig. 2. Magnesium, sodium, and potassium concentrations remain relatively constant between 1 and $5 \mathrm{mg} \mathrm{L}^{-1}$ over the $240 \mathrm{~h}$ period, indicating that dissolution of major phases within the fly ash is negligible over the time period studied. However, calcium concentrations increase slightly (by $4 \mathrm{mg} \mathrm{L}^{-1}$ in EMR and $1-2 \mathrm{mg} \mathrm{L}^{-1}$ in ARD elutriates). The dissolution of alkaline calcium phases could partially explain the increase in $\mathrm{pH}$ although there is no $\mathrm{pH}$ increase during the first $48 \mathrm{~h}$ concurrent with increases observed in dissolved calcium concentrations.

Several elements (e.g., beryllium, thallium, cadmium, chromium, nickel, and silver) were never measured above the $0.001 \mathrm{mg} \mathrm{L}^{-1}$ reporting limit, while barium, arsenic, selenium, and vanadium exhibit increases and manganese exhibits a decrease in concentration over the $10 \mathrm{~d}$ experiment. Concentrations of these latter elements are plotted in Fig. 3, and show that arsenic concentrations in the Emory River aerated elutriate reached about
$0.050 \mathrm{mg} \mathrm{L}^{-1}$ and near $0.060 \mathrm{mg} \mathrm{L}^{-1}$ in the nitrogen system. However, arsenic concentrations in the ash recovery ditch elutriates exceeded $0.080 \mathrm{mg} \mathrm{L}^{-1}$ after $240 \mathrm{~h}$ of agitation, which is near the concentration measured in the field-collected ash recovery ditch site water (Table 2). The $10 \mathrm{~d}$ agitation of the fly ash in the site water allows additional dissolution of metals from the fly ash material compared to actual site conditions. However, as noted in Fig. 3, the constituent concentrations began to plateau, indicating that the most mobile phases have been exhausted. It should be noted that, the arsenic concentrations measured at $240 \mathrm{~h}$ are below the Criterion Continuous Concentration (CCC) of $0.150 \mathrm{mg} \mathrm{L}^{-1}$ for the protection of aquatic life (US EPA, 2002).

Vanadium concentrations increase from 0.015 to near $0.030 \mathrm{mg} \mathrm{L}^{-1}$ in the Emory River elutriates over the $10 \mathrm{~d}$ experiment. The vanadium concentrations in the ash recovery ditch elutriate were higher, near $0.055 \mathrm{mg} \mathrm{L}^{-1}$, yet remain relatively constant over the $10 \mathrm{~d}$ test period indicating the most mobile vanadium phases had already been exhausted. The field collected stilling pond effluent water contained approximately $0.032 \mathrm{mg} \mathrm{L}^{-1}$ dissolved vanadium which closely matches the Emory River elutriate systems. The higher concentrations observed in the ash
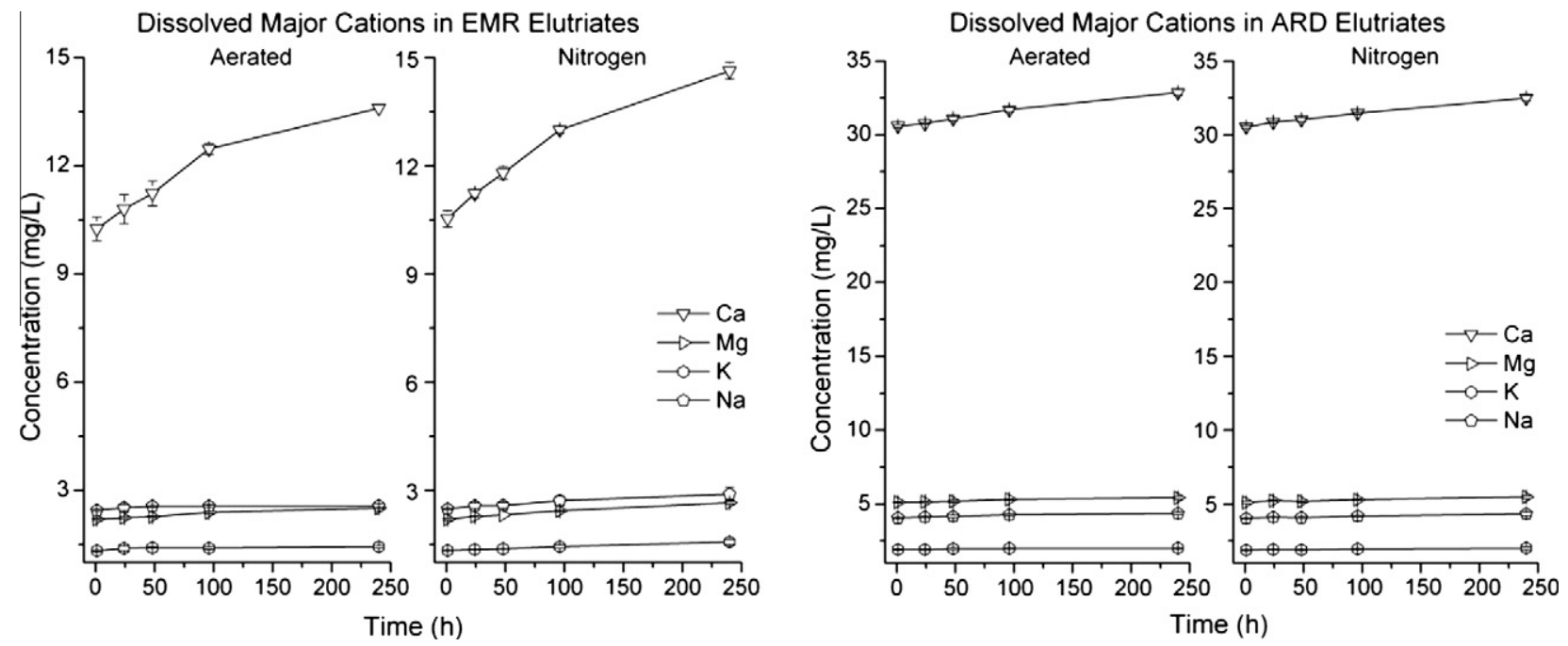

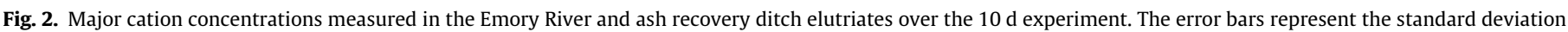
of measurements on triplicate elutriate preparations.
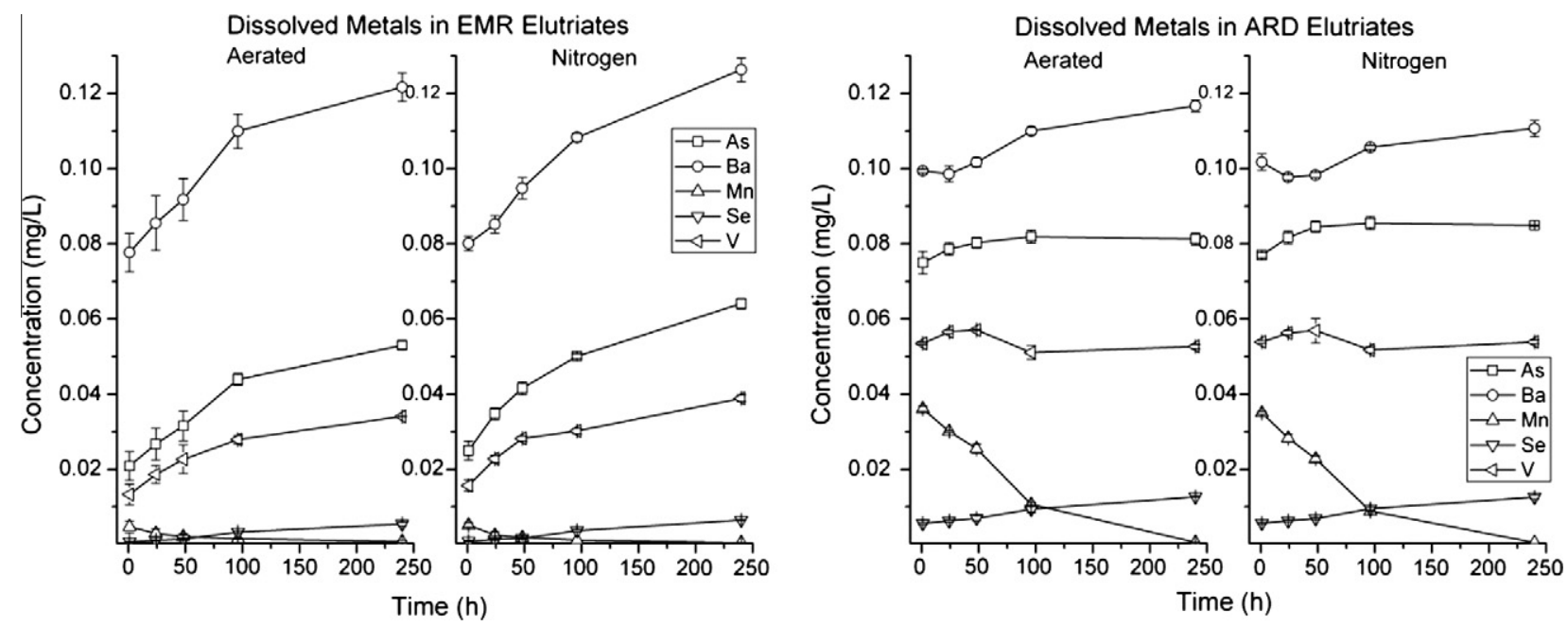

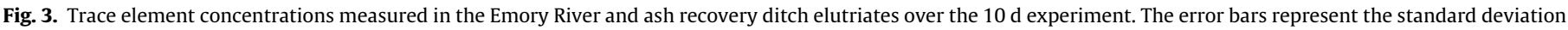
of measurements on triplicate elutriate preparations. 
recovery ditch elutriates are likely due to the higher solids loading, allowing additional vanadium to dissolve or desorb, as well as the higher initial water vanadium concentration (Table 2). Selenium concentrations increased in all four elutriate systems over the $10 \mathrm{~d}$ experiment, from $<0.001$ to $0.005 \mathrm{mg} \mathrm{L}^{-1}$ in the Emory River systems and from 0.005 to $0.013 \mathrm{mg} \mathrm{L}^{-1}$ in the ash recovery ditch elutriates. The Emory River elutriate final concentration is near the $0.0059 \mathrm{mg} \mathrm{L}^{-1}$ value measured in the field-collected ash recovery ditch water (Table 2 ), yet the ash recovery ditch elutriate produced a final selenium concentration of $0.013 \mathrm{mg} \mathrm{L}^{-1}$, indicating selenium concentrations can increase due to additional agitation and dissolution time and the amount of fly ash present. The ARD elutriate selenium concentrations exceed the CCC of $0.005 \mathrm{mg} \mathrm{L}^{-1}$ provided for total recoverable selenium and dissolved selenium ( $\left.0.0046 \mathrm{mg} \mathrm{L}^{-1}\right)$ calculated using the conversion factor of 0.922 provided in US EPA guidance (2002).

Manganese concentrations, however, decreased in all four systems during the $10 \mathrm{~d}$ elutriate tests, from an initial value of $0.005 \mathrm{mg} \mathrm{L}^{-1}$ to $<0.001 \mathrm{mg} \mathrm{L}^{-1}$ in the Emory River elutriates and from 0.035 to $<0.001 \mathrm{mg} \mathrm{L}^{-1}$ in the ash recovery ditch elutriates. Oxidation of manganese in the nitrogen-bubbled elutriate systems suggested completely nitrogen-purged conditions were not achieved, however, the redox potentials measured (Fig. 1) still indicate that the conditions were sufficient for manganese oxidation. A similar trend is observed in the dissolved manganese concentra- tions in the field-collected ash recovery ditch and stilling pond effluent waters, where dissolved manganese decreases from 0.030 to $<0.001 \mathrm{mg} \mathrm{L}^{-1}$, respectively (Table 2 ). Oxidation of $\mathrm{Mn}$ (II) to $\mathrm{Mn}(\mathrm{IV})$ and subsequent precipitation of manganese dioxide would decrease dissolved manganese concentrations and provide, along with concomitant iron phases, additional sorption substrates for other elements, although sorption is dependent upon water chemistry ( $\mathrm{pH}$, organic carbon, ionic strength, etc.).

In addition to dissolved metals concentrations, arsenic and selenium speciation was also determined by HPLC-ICP-MS over the course of the $10 \mathrm{~d}$ elutriate experiment. Dissolved species measurements were used to examine the effects of the aerated and nitrogen-purged treatments on the fly ash elutriate systems, and to determine potential redox transformations that may occur in these systems. The measured speciation data in Fig. 4 demonstrate the redox stability of the dissolved species in the elutriate solutions over the course of the $10 \mathrm{~d}$ study. Arsenic speciation data show that the increase in dissolved arsenic was attributed to an increase in arsenic (V), i.e., arsenate. Only five detections of As(III) near the $0.002 \mathrm{mg} \mathrm{L}^{-1}$ reporting limits were observed in these systems ( $T=1 \mathrm{~h}$ in aerated and nitrogen EMR and $T=1,24,96 \mathrm{~h}$ in nitrogen ARD systems), even under nitrogen-purged conditions.

The measured speciation data show the increase in dissolved selenium concentration (Fig. 4) was attributed solely to an increase in $\mathrm{Se}(\mathrm{IV})$, i.e., selenite. No Se(VI), i.e., selenate, was detected in any
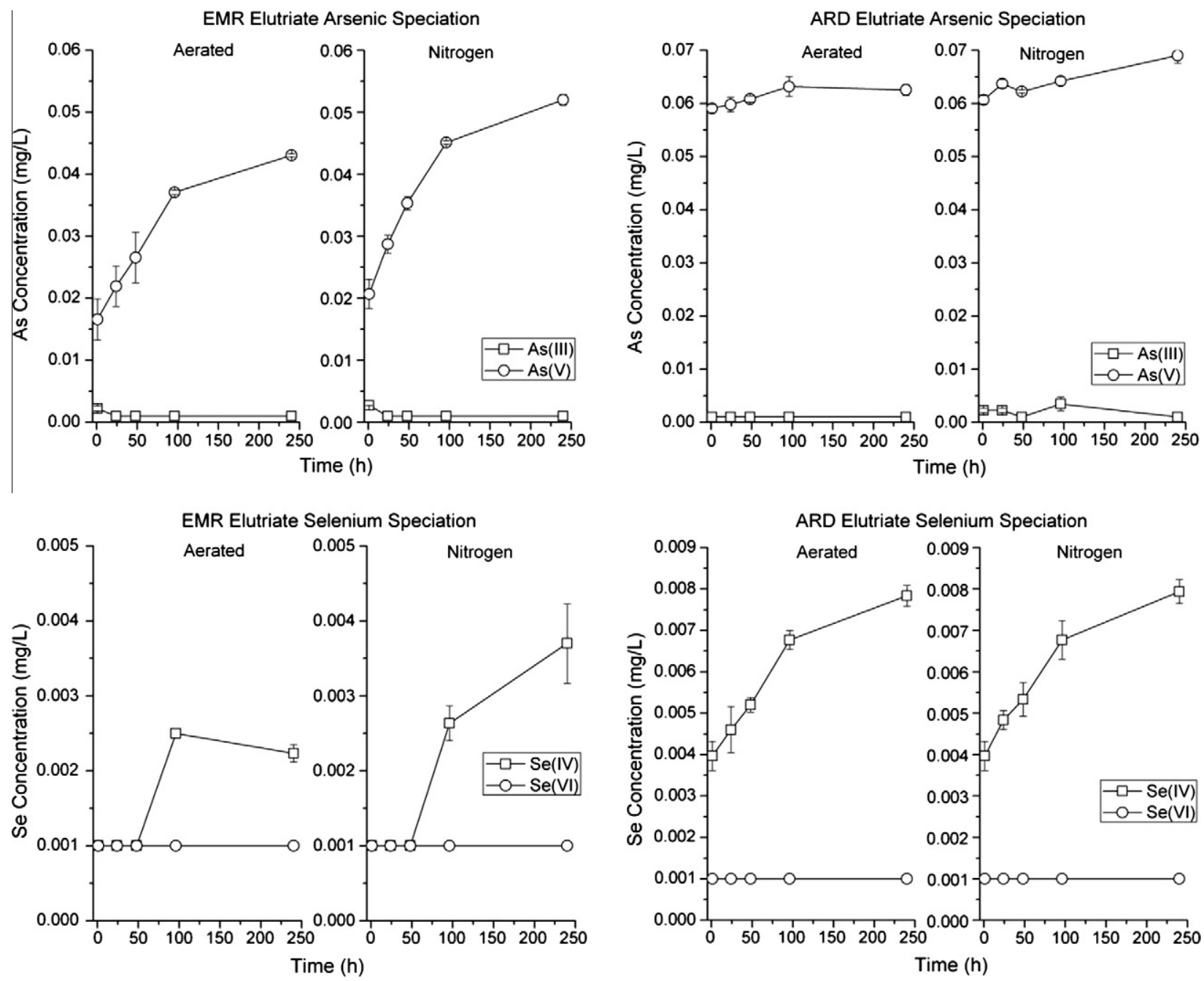

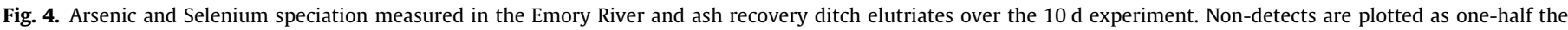
method reporting limit of $0.002 \mathrm{mg} \mathrm{L}^{-1}$. The error bars represent the standard deviation of measurements on triplicate elutriate preparations. 

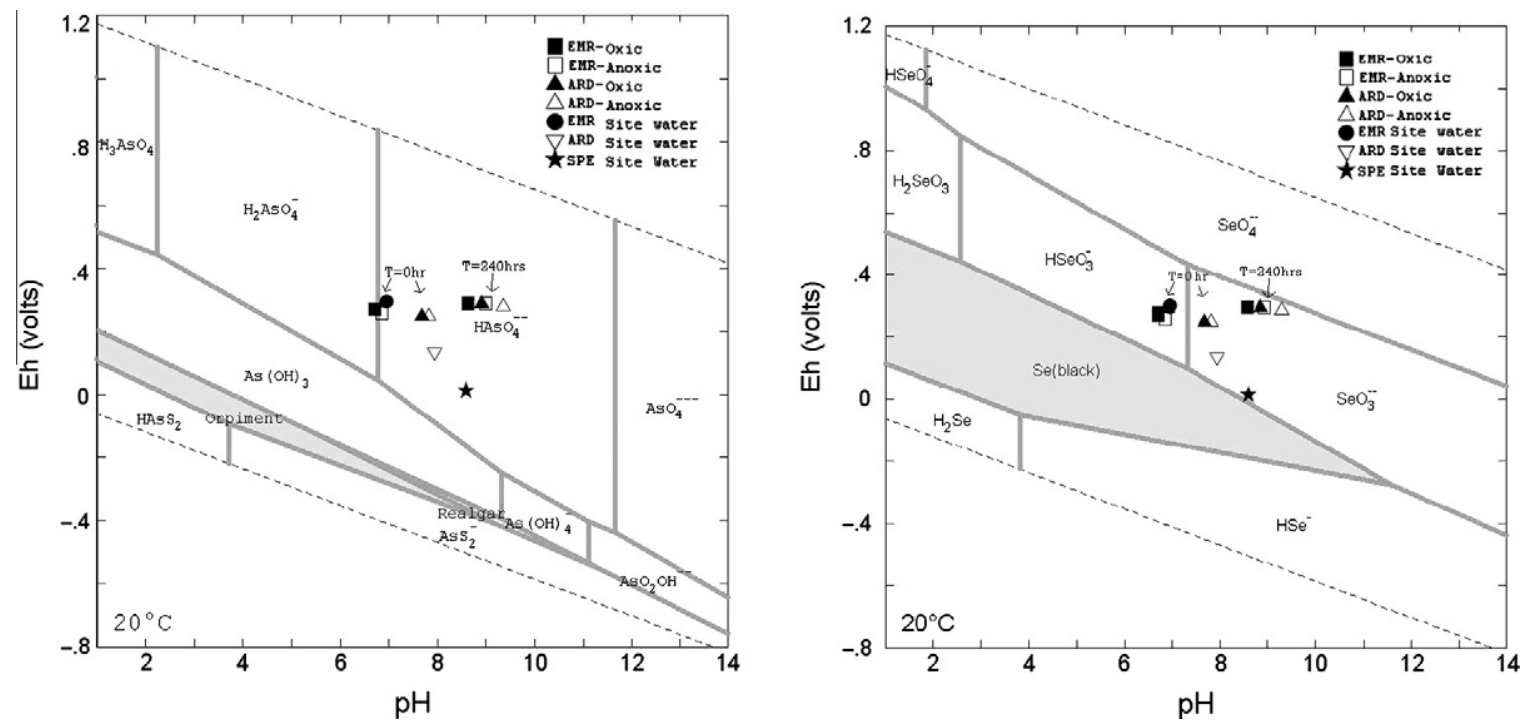

Fig. 5. Eh-pH stability fields for various arsenic and selenium compounds with values for elutriates and field waters plotted over the calculated species stability fields.

of the elutriates above the $0.002 \mathrm{mg} \mathrm{L}^{-1}$ reporting limit, even after $10 \mathrm{~d}$ of aeration. The Eh and $\mathrm{pH}$ values measured for the $T=0$ and $240 \mathrm{~h}$ time points are plotted over the calculated stability fields for arsenic and selenium compounds, as shown in Fig. 5. The systems agitated with air or nitrogen demonstrate increases in Eh and $\mathrm{pH}$ values over the $10 \mathrm{~d}$ experiment (Figs. 1, 4 and 5), yet the measured conditions remain in the selenite and arsenate stability fields. There is a noticeable trend toward the selenate stability field by $240 \mathrm{~h}$, yet even after $10 \mathrm{~d}$ of aeration, selenite is still the stable species. This suggests that even with aeration, the redox potential of the system is poised such that selenite is the stable species (Geological Survey of Japan, 2005).

Comparison of the measured dissolved metals concentrations (Fig. 3 and Table 2) and species concentrations data (Fig. 4 and Table 2) shows slightly lower values for the speciation summation results, which suggest that there are small colloidal particles that pass through the $0.45 \mu \mathrm{m}$ filter. These small particles are measured by ICP-MS and included in the 'dissolved' fraction; however, these particles are effectively removed by the HPLC separation column, yielding a slightly lower concentration by summation of species, however, the agreement observed is consistent within analytical error. The HPLC-ICP-MS chromatograms were reviewed for the presence of other compounds, such as organoarsenicals, yet none were observed.

In general, concentrations of metals observed in the elutriate test systems agree with measured concentrations from fieldcollected samples, indicating that the laboratory elutriate test systems were a reasonable simulation of field site conditions with extended agitation time. The arsenic speciation results for the elutriate experiments are in qualitative agreement with the fieldcollected waters in which only arsenate was detected in the ash recovery ditch and stilling pond effluent waters, as shown in Table 2 and Fig. 5. This suggests that arsenate is the thermodynamically stable species in these systems (Vink, 1996; Geological Survey of Japan, 2005). Selenium speciation of the field-collected ash recovery ditch water also agrees with the elutriate experiments, in which only selenite is observed (Table 2 and Fig. 5). However, the stilling pond effluent sample collected in the field contains both selenite and selenate, whereas no selenate was observed in any of the laboratory elutriate systems. The Eh and $\mathrm{pH}$ values measured for the field-collected waters are also plotted over the calculated stability fields in Fig. 5, which also support the measured arsenate and selenite species observed.
The apparent discrepancy between the single stilling pond effluent field sample and laboratory elutriate selenium speciation could be the result of photooxidation reactions. Water in the stilling pond has a residence time of approximately 2-3 d under the dredging conditions during this study, and contains dissolved organic carbon and suspended iron phases which are photoactive (Khoe et al., 2000; Emett and Khoe, 2001). These compounds can photoreduce, thereby creating hydroxyl radicals and other oxidant species which could oxidize selenium species to selenate in a manner similar to that previously reported for arsenic (Hall et al., 1999; Khoe et al., 2000; Emett and Khoe, 2001; Hug et al., 2001; Bednar et al., 2003). Although this hypothesis is based on a single field collected sample, it remains an active area of investigation for this system.

\section{Conclusions}

A series of extended elutriate experiments were performed to determine the potential for metals release from fly ash as the result of dredging operations at the Tennessee Valley Authority Kingston Fossil Plant fly ash spill. Additionally, arsenic and selenium speciation were investigated to determine the redox stability of various species in these systems. Results suggested that only manganese was subject to oxidation by atmospheric oxygen over the time period studied (10 d), as evidenced by a decrease in dissolved manganese concentrations over the elutriate test period. Concentrations of arsenic, selenium, barium, and vanadium generally increased over this time period, with the speciation of dissolved arsenic and selenium remaining unchanged. Only arsenate and selenite were observed in the laboratory elutriate systems and were predicted to be thermodynamically stable based on measured Eh and pH conditions (Vink, 1996; Geological Survey of Japan, 2005). These laboratory speciation data agreed with limited field-collected waters with the exception of a single detection of selenate in the stilling pond effluent water, which could be the result of photolysis reactions as the Eh and $\mathrm{pH}$ conditions of the field waters also predict arsenate and selenite to be stable. Overall, the data reported indicated that dissolution reactions more so than redox shifts will control metals release from fly ash in these systems.

\section{Acknowledgments}

The use of trade, product, or firm names in this report is for descriptive purposes only and does not imply endorsement by 
the US Government. The tests described and the resulting data presented herein, unless otherwise noted, were obtained from research conducted under IAG 00076492 for the Tennessee Valley Authority, the Tennessee Department of Environment and Conservation, and the Environmental Quality and Installations program of the US Army Corps of Engineers by the US Army Engineer Research and Development Center. Permission was granted by the Chief of Engineers to publish this information. The findings of this report are not to be construed as an official Department of the Army, Tennessee Valley Authority, or Tennessee Department of Environment and Conservation position unless so designated by other authorized documents. The authors thank Susan Bailey and Burton Suedel of the USAERDC for their editorial comments and Jonathan Burr of TDEC for assistance in collection of field samples.

\section{References}

Baba, A., Gurdal, G., Sengunalp, F., Ozay, O., 2008. Effects of leachant temperature and $\mathrm{pH}$ on leachability of metals from fly ash. A case study: can thermal power plant, province of Canakkale, Turkey. Environ. Monit. Assess. 139, 287-298.

Bednar, A.J., Garbarino, J.R., Ranville, J.F., Wildeman, T.R., 2002. Preservation of inorganic arsenic species in groundwater and acid mine drainage samples. Environ. Sci. Technol. 36, 2213-2218.

Bednar, A.J., Garbarino, J.R., Ferrer, I., Rutherford, D.W., Wershaw, R.L., Ranville, J.F., Wildeman, T.R., 2003. Photodegradation of Roxarson in Poultry Litter Leachates. Sci. Total Environ. 302, 237-245.

Bednar, A.J., Garbarino, J.R., Burkhardt, M.R., Ranville, J.F., Wildeman, T.R., 2004. Field and laboratory arsenic speciation methods and their application to natural water matrices. Water Res. 38, 355-364.

Bednar, A.J., Kirgan, R.A., Jones, W.T., 2009. Comparison of standard and reaction cell inductively coupled plasma mass spectrometry in the determination of chromium and selenium species by HPLC-ICP-MS. Anal. Chim. Acta 632, 27-34.

Besser, J.M., Giesy, J.P., Brown, R.W., Buell, J.M., Dawson, G.A., 1996. Selenium bioaccumulation and hazards in a fish community affected by coal fly ash effluent. Ecotoxicol. Environ. Saf. 35, 7-15.

Carlson, C.L., Adriano, D.C., 1993. Environmental impacts of coal combustion residues. J. Environ. Qual. 22, 227-247.

Chatterjee, R., 2009. Environews forum: TVA Spill's chemical legacy. Environ. Health Perspect. 117, A346.

Chaudhary, S., Banerjee, D.K., 2007. Speciation of some heavy metals in coal fly ash. Chem. Speciation Bioavailability 19, 95-102.

Cherry, D.S., Larrick, S.R., Gunthrie, R.K., Davis, E.M., Sherberger, F.F., 1979. Recovery of invertebrate and vertebrate populations in a coal ash stressed drainage system. J. Fishes Res. Board Canada 36, 1089-1096.

Cherry, D.S., Guthrie, R.K., Davis, E.M., Harvey, R.S., 1984. Coal ash basin effects (particulates, metals, acidic $\mathrm{pH}$ ) upon aqautic biota: an eight-year evaluation. Water Resour. Bull. 20, 535-544.

DiGiano, F.A., Miller, C.T., Yoon, J., 1995. Dredging Elutriate Test Development. Dredging Operations Technical Support Program, Contract Report D-95-1. 79pp.

Eary, L.E., Rai, D., Mattigold, S.V., Ainsworth, C.C., 1990. Geochemical factors controlling the mobilization of inorganic constituents from fossil fuel combustion residues: II. Review of the minor elements. J. Environ. Qual. 19, 202-214.

Emett, M.T., Khoe, G.H., 2001. Photochemical oxidation of arsenic by oxygen and iron in acidic solutions. Water Res. 35, 649-656.

Felt, D.R., Bednar, A.J., Georgian, T., 2008. The effects of grinding methods on metals concentrations in soil. Talanta $77,380-387$.
Geological Survey of Japan, 2005. Atlas of Eh-pH Diagrams. Open File Report No. 419.

Gieré, R., Carleton, L.E., Lumpkin, G.R., 2003. Micro- and nanochemistry of fly ash from a coal-fired power plant. Am. Mineral. 88, 1853-1865.

Guthrie, R.K., Davis, E.M., Cherry, D.S., Walton, J.R., 1982. Impact of coal ash from electric power production on changes in water quality. Water Resour. Res. 18, 135-138.

Hall, G.E.M., Pelchat, J.C., Gauthier, G., 1999. Stability of inorganic arsenic (III) and arsenic (V) in water samples. J. Anal. Atom. Spectrom. 14, 205-213.

Hug, S.J., Canonica, L., Wegelin, M., Gechter, D., von Gunten, U., 2001. Solar oxidation and removal of arsenic at circumneutral $\mathrm{pH}$ in iron containing waters. Environ. Sci. Technol. 35, 2114-2121.

Khoe, G.H., Emett, M.T., Zaw, M., and Prasad, P., 2000. Removal of arsenic using advanced oxidation processes. In: Minor Elements 2000: Processing and Environmental aspects of $\mathrm{As}, \mathrm{Sb}$, Se, Te, and Bi. Littleton, CO, Society for Mining, Metallurgy, and Exploration.

Kuzmick, D.M., Mitchelmore, C.L., Hopkins, W.A., Rowe, C.L., 2007. Effects of coal combustion residues on survival, antioxidant potential, and genotoxicity resulting from full-lifecycle exposure of grass shrimp (Palaemonetes pugio Holthius). Sci. Total Environ. 373, 420-430.

Light, T.S., 1972. Standard solution for redox potential measurements. Anal. Chem. 44, 1038-1039.

Mattigold, S.V., Rai, D., Eary, L.E., Ainsworth, C.C., 1990. Geochemical factors controlling the mobilization of inorganic constituents from fossil fuel combustion residues: I. Review of the major elements. J. Environ. Qual. 19, $188-201$.

Palermo, M.R., Schroeder, P.R., Estes, T. J., Francingues, N.R., 2008. Technical Guidelines for Environmental Dredging of Contaminated Sediments. ERDC/EL TR-08-29, US Army Engineer Research and Development Center, Vicksburg, MS

Pennsylvania Department of Environmental Protection, 2005. DEP Issues Permit Modification That Allows PPL to Reopen Reinforced Fly Ash Basin. Press Release, December 27, 2005. DEP Northeast Region, Wilkes-Barre, Pennsylvania. <http:// www.depweb.state.pa.us/permits/cwp/view.asp?a=3\&q=497731>.

Rowe, C.L., Hopkins, W.A., Congdon, J.D., 2002. Ecotoxicological implications of aquatic disposal of coal combustion residues in the United States: a review. Environ. Monit. Assess. 80, 270-276.

Roy, W.R., Thiery, R.G., Schuller, R.M., Suloway, J.J., 1981. Coal fly ash: a review of the literature and proposed classification system with emphasis on environmental impacts. Illinois institute of natural resources, state geological survey division. Environ. Geol. Notes 96. April 1981.

Ruhl, L., Vengosh, A., Dwyer, G.S., Hsu-Kim, H., Deonarine, A., Bergin, M., Kravchenko, J., 2009. Survey of the potential environmental and health impacts in the immediate aftermath of the coal ash spill in Kingston, TN. Environ. Sci. Technol. 43, 6326-6333.

Tennessee Valley Authority, 2009. Action Memorandum: Request for Removal Action at the TVA Kingston Fossil Fuel Plant Release Site, Roane County Tennessee. <http://www.tva.gov/kingston/memo.htm> (accessed 04.08.09).

US Environmental Protection Agency, 2002. National Recommended Water Quality Criteria, EPA/822/R/02/047; US Environmental Protection Agency, Office of Water, Washington, DC, 2002.

US Army Corps of Engineers, 2003. Evaluation of Dredged Material Proposed for Disposal at Island, Nearshore, or Upland Confined Disposal Facilities - Testing Manual, ERDC/EL TR-03-1, US Army Engineer Research and Development Center, Vicksburg, MS.

US Environmental Protection Agency, 2007. SW-846 Methods for the Analysis of Hazardous Waste.

US Environmental Protection Agency, 2009. EPA to oversee cleanup of TVA Kingston Fossil Fuel Plant release. Press Release, May 11, 2009. EPA Region 4, Office of External Affairs, Atlanta, Georgia. <http://www.epakingstontva.com/ EPA\%200rder/Forms/Allitems.aspx>.

Vink, B.W., 1996. Stability relations of antimony and arsenic compounds in the light of revised and extended Eh-pH diagrams. Chem. Geol. 130, 21-30. 